\title{
Jakobson's Outstanding of his Contribution to the History Czechoslovak Cultural Studies and Research
}

\author{
Sorin Paliga (Bucharest)
}

\begin{abstract}
Roman Jakobson: Moudrost starých Čechů. Komentovaná edice s navazující exilovou polemikou. K vydání připravili a studií doprovodili Tomáš Hermann a Miloš Zelenka. Praha - Červený Kostelec: Ústav pro soudobé dějiny AV ČR, v.v.i. - nakladatelství Pavel Mervart, 2015. 382 s. ISBN 978-80-7465-112-0 (Pavel Mervart), 978-80-7285-185-0 (Ústav pro soudobé dějiny AV ČR, v. v. i.).
\end{abstract}

(The Wisdom of the Old Czechs. Commented edition with related polemics of the exile. Edited and commented by Tomáš Hermann and Miloš Zelenka)

Roman Jakobson is, beyond much doubt, one of the most influential linguists of the 20th century. This is the definition on Wikipedia, and a "classical" definition in, perhaps, any work dedicated to Jakobson. Less known is his activity in Prague and, for some time, also in Brno after the first World War, first as a representative of the Soviet diplomatic mission. He gradually departed from the Soviet régime and, without becoming a dissident, continued his cultural and scientific activity, predominantly within the Prague School of Linguistics (Pražská lingvistická škola or, better, Pražský lingvistický kroužek, PLK), chaired by Vilém Mathesius, for many years Jakobson being its vice-chair. Jakobson was, we might say, a connector of two big cultures: Russia, on the one hand, Western Europe and United States, on the other.

The book under scrutiny begins with an ample and dense analysis of the historical, political and cultural atmosphere of the 1920s and 1930s in Czechoslovakia. There was, immediately after the Great War, an enthusiastic approach to a new life of the newly created Czechoslovak state, dominated by the colossal figure of Tomáš Garrigue Masaryk, but also populated by a large and very consistent group of intellectuals, with whom Jakobson had close ties. It was also, as the 1920 s witnessed, the rise and ascension of the extreme right, which gained more and more ground in Hungary, Italy and, decisively, in Germany. The Wisdom of the Old Czechs is, first of all, a political text with incursions (and excursions) in the fascinating past of the Czech people, from the beginnings of Magna Moravia, if not earlier, the ephemeral kingdom of Samo, a merchant converted to politics in the turbulent years of the 7th c. C.E., through the glorious Middle Ages, the age of Jan Hus and Charles IV, to the contemporary Czechoslovakia, dominated by Masaryk.

As the editors note in the very title of their ample introduction, Jakobson's text is a "war chronicle" (válečný spis), written within the extremes delimited by structural linguistics, Slavic studies and political ideology. Jakobson wished to study in Prague as early as 1914, when he applied to Karl Ferdinand University in Prague (the then name of the university). With his Russian-Jewish origins, Jakobson had to learn Czech, and he succeeded within a short time, due to his native linguistic gift, but also to the multilingual atmosphere at home. His career began under the sign of the new Soviet régime, which he tried to serve, initially in Tallinn, then in Prague. His contemporaries were not all enthusiastic with the newcomer, characterized as a "snake," "impostor" ("podvodnik"), 'bastard' etc. As a representative of the Soviet mission, such epithets may not be surprising. The situation gradually changed after 1925, when he finally put an end to his diplomatic career, and then dedicated his life to a long activity as a linguist, and also got involved in an impressive 
palette of cultural activities. A climax in these years was represented by his doctoral thesis finalized in 1930 at Charles University (Karlova univerzita). Three years later, in 1933, he became professor at the University in Brno (now Masaryk University).

An essential feature of Jakobson's activity is that he simply got fond of Czechoslovakia and of czechoslovakism (čechoslovakismus), a political but also cultural influential trend after WWI in Czechoslovakia, having the solid support of Masaryk and of most, if not all, Czech and Slovak intellectuals. It also was the ideological fundament of the Czechoslovak state, represented by the two nations, the Czechs and the Slovaks. This ideological approach explains why Jakobson chose Magna Moravia (Velká Morava) as his heroic example for the whole history of Central Europe, and of all Slavs in general.

The Wisdom of the Old Czechs (Moudrost starých Čechů) is a text written and published in exile: 1943, New York, where Jakobson settled in the wake of the great purges and antisemitic movements in Germany and, gradually, in all conquered countries. It was initially published as a serial in the Sunday supplement of the Newyorské listy (New York News), a publication of the Czechoslovak exile. Magna Moravia, the glorious Central European state of the Slavs, from which both the Czechs and the Slovaks derive culturally, politically and linguistically, is seen by Jakobson as the most relevant moment in those times, a model to be followed not only by the Slavs, but by all nations around. As noted above, this is a predominantly political text, deeply influenced by the great sympathy Jakobson had for Czechoslovakia, and also by the tragic experience of the Nazi ideology. He points out that the Czechs should not be affected by a certain complex of inferiority (komplex ménécennosti, p. 112). Magna Moravia is seen as the back projection of Czechoslovakia, because this period is one of a full political and cultural unity of the two Slavic branches, Czech and Slovak (p. 113), characterized as a long-lasting historical determination (trvalá dějinná směrodatnost tohoto obdobi).
As the present (the 1930s and 1940s) is mirrored in the past, and in order to give an impulse to the internal resistance in the occupied Czechoslovakia, which he left under the pressure of the political events, the German aggression towards east (Drang nach Osten) is analysed in the days of Magna Moravia, and found identical to the political and military events of WWII. The cultural activity of Constantine the Philosopher is seen as the origin of the Czechoslovak national ideology (p. 120). This indeed corresponds to the historical facts, as the two brothers from Thessaloniki, the translators of the Bible into Slavic, i.e. the dialect spoken in their place of origin, first went to Magna Moravia in order to find political support for their work, and then travelled to Rome, in order to find the supreme support, the ecclesiastical one. Finally, in order to complete the parallel past $\sim$ present, the German anti-Slavic activity during and after the glorious period of Magna Moravia is labelled "the fifth column," a transparent allusion to Hitler's use of the German minority as a forceful political pressure.

We should not imagine that Jakobson's text was without polemical reactions. This is normal. Now, we all know that WWII ultimately ended with the triumph of a large anti Nazi coalition. Then, in 1943, things were not so clear or not so clear to all. From the perspective of some intellectuals, then like now, many parts of the text may seem extremely "patriotic," but without the scientific support required for such a study. This is, of course, true. We must hasten to add that Jakobson was of course aware of all these attitudes and, given the high position of the author, we should allow him the right to use stylistic methods and "patriotic," philo-Czech attitudes in order to create the necessary atmosphere of resistance against the aggressor.

The editors, also the authors of a wonderful and ample introduction, Tomáš Hermann and Miloš Zelenka, must be congratulated for this superb cultural achievement, to turn The Wisdom of the Old Czechs into an accessible, and easily readable volume.

E-mail: sorin.paliga@lls.unibuc.ro 